\section{(6) OPEN ACCESS}

\title{
Interventions to reduce inequalities in vaccine uptake in children and adolescents aged $<19$ years: a systematic review
}

\author{
Tim Crocker-Buque, ${ }^{1}$ Michael Edelstein, ${ }^{2}$ Sandra Mounier-Jack ${ }^{1}$
}

\begin{abstract}
- Additional material is published online only. To view please visit the journal online (http://dx.doi.org/10.1136/jech2016-207572).

${ }^{1}$ Health Protection Research Unit in Immunisation, Faculty of Public Health and Policy, London School of Hygiene and Tropical Medicine, London, UK ${ }^{2}$ Department of Immunisation, Hepatitis and Blood Safety, Public Health England, London, UK
\end{abstract}

\section{Correspondence to} Dr Tim Crocker-Buque, Health Protection Research Unit in Immunisation, Faculty of Public Health and Policy, London School of Hygiene and Tropical Medicine, 15-17 Tavistock Place, London WC1H 9SH, UK; timothy.crocker-buque@lshtm. ac.uk

Received 29 March 2016 Revised 13 June 2016 Accepted 4 July 2016 Published Online First 17 August 2016

\begin{abstract}
Background In high-income countries, substantial differences exist in vaccine uptake relating to socioeconomic status, gender, ethnic group, geographic location and religious belief. This paper updates a 2009 systematic review on effective interventions to decrease vaccine uptake inequalities in light of new technologies applied to vaccination and new vaccine programmes (eg, human papillomavirus in adolescents).
\end{abstract}

Methods We searched MEDLINE, Embase, ASSIA, The Campbell Collaboration, CINAHL, The Cochrane

Database of Systematic Reviews, Eppi Centre, Eric and PsychINFO for intervention, cohort or ecological studies conducted at primary/community care level in children and young people from birth to 19 years in OECD countries, with vaccine uptake or coverage as outcomes, published between 2008 and 2015.

Results The 41 included studies evaluated complex multicomponent interventions ( $n=16)$, reminder/recall systems ( $n=18)$, outreach programmes $(n=3)$ or computer-based interventions $(n=2)$. Complex, locally designed interventions demonstrated the best evidence for effectiveness in reducing inequalities in deprived, urban, ethnically diverse communities. There is some evidence that postal and telephone reminders are effective, however, evidence remains mixed for textmessage reminders, although these may be more effective in adolescents. Interventions that escalated in intensity appeared particularly effective. Computer-based interventions were not effective. Few studies targeted an inequality specifically, although several reported differential effects by the ethnic group.

Conclusions Locally designed, multicomponent interventions should be used in urban, ethnically diverse, deprived populations. Some evidence is emerging for text-message reminders, particularly in adolescents. Further research should be conducted in the UK and Europe with a focus on reducing specific inequalities.

\section{INTRODUCTION}

In high-income countries, substantial differences exist in vaccine uptake relating to socioeconomic status, gender, ethnic group, geographic location and religious belief. ${ }^{1-24}$ In 2009, the National Institute for Health and Care Excellence (NICE) conducted a systematic review of effectiveness and cost-effectiveness of interventions to 'reduce differences in the uptake of immunisations in children and young people under the age of 19 years'. ${ }^{19}$ Since then new technologies have emerged, including data systems and online interventions, and have been applied to vaccination. In addition, new programmes have been implemented, such as human papillomavirus (HPV) vaccine in adolescents. An updated review of the evidence is therefore warranted. The aim of this study is to update the 2009 NICE systematic review, focusing and refining the recommendations on effective interventions to decrease vaccine uptake inequalities in high-income countries.

\section{MATERIALS AND METHODS}

We repeated the NICE guidance methodology, ${ }^{19} 25$ conducting our review in line with the Preferred Reporting Items for Systematic Reviews and Meta-Analysis (PRISMA) statement. ${ }^{26}$

\section{Search strategy}

We searched MEDLINE, Embase, ASSIA, The Campbell Collaboration, CINAHL, The Cochrane Database of Systematic Reviews, Eppi Centre, Eric and PsychINFO using the strategy described in online supplementary appendix 1. Results were limited to publications in English from April 2008 until November 2015.

\section{Inclusion and exclusion criteria}

We included studies with the following characteristics:

- Study design: randomised controlled trials (RCTs), quasi-experimental (including interrupted time series and before-and-after studies), ecological and observational cohort studies.

- Population: children and young people (CYP) from birth to 19 years in OECD countries. ${ }^{27}$

- Intervention: delivered at primary/community care level, with the aim of increasing vaccine uptake in a specific population or in the overall population, with outcomes reported for specific subgroups.

- Outcomes: vaccine uptake, including initiation of vaccination course, schedule completion, being up-to-date (UTD) for age, or coverage, with either a focus on reducing inequalities or where outcomes in different population groups are reported.

In addition, we included references from review articles or protocols identified in the search that fitted inclusion criteria, but we did not consider inequalities.

\section{Study selection process}

One reviewer initially screened articles on title and manually de-duplicated records. Two reviewers screened potentially relevant abstracts independently. Any disagreement was resolved by discussion on the basis of the inclusion criteria. Both reviewers agreed the final inclusions. 


\section{RESULTS}

The study selection process is presented in online supplementary figure S1. Of 12386 unique articles, 315 abstracts were screened. Of these, 80 full text articles were reviewed, along with 23 studies identified from the references of 22 review articles or protocols. ${ }^{28-49}$

In total, 41 studies were included $(17$ RCTs, 20 quasi-experimental and 4 retrospective cohort studies), which were conducted in the USA $(n=31)$, the UK $(n=5)$, Canada $(n=3)$ and Australia $(n=2)$.

Studies reported on multicomponent complex interventions $(n=16)$, patient-focused reminder/recall systems $(n=18)$, outreach programmes $(n=3)$, prompts for healthcare workers (HCWs) $(n=2)$ and computer-based interventions $(n=2)$.

We categorised results by using the intervention type and by vaccinations for the age group:

- Childhood vaccines from birth to age 11 (singly or in combination): tetanus, diphtheria and pertussis (TDaP); polio (IPV); haemophilus influenza b (Hib); pneumococcal (PCV); rotavirus; meningitis $\mathrm{B}(\mathrm{MenB})$; meningitis C (MenC); measles, mumps and rubella (MMR).

- Adolescent vaccines from age 11 to 19 (singly or in combination): HPV, MenC, quadrivalent meningitis (Men4) and relevant boosters.

- Seasonal influenza alone in CYP.

The terms 'uptake' and 'coverage' were used inconsistently in the literature. We have defined 'uptake' as the proportion of the eligible population who received a vaccine during a specific time period and 'coverage' as the proportion of an eligible population that is vaccinated, regardless of when they received the vaccine.

\section{Complex interventions}

Complex interventions comprise several interacting components that may impact on a range of outcomes or have variability in delivery. ${ }^{50}$ Table 1 describes intervention components, sample size and study outcomes.

\section{Childhood vaccinations}

Six studies showed evidence of effectiveness for locally developed complex interventions to increase uptake in ethnically diverse, low-income populations. In the USA, a retrospective evaluation of 'Start Right', a community-developed intervention involving bilingual promotional materials, peer health educators, outreach, parental reminders and provider support, found that children aged 19-35 months enrolled in the programme had significantly higher uptake than control children. ${ }^{51}$ Another intervention involving reminder/recall systems, increased clinic access, use of standing orders and provision of educational materials was evaluated in a before-and-after study, which found that children in the intervention year had a statistically significant increase in vaccine uptake. ${ }^{52}$ An intervention identifying children not UTD attending a charitable community organisation for resource-poor families, providing information and vaccinations, followed by reminders, increased coverage rates after 9 months. ${ }^{53}$ In Canada, an evaluation of the 'Families First' programme (involving identification of high-risk families, home visiting and signposting to health services) found small but significant increases in being UTD by first and second birthdays. ${ }^{54}$ An RCT evaluating an intervention that escalated in intensity on the basis of vaccine status over time, which involved universal, language appropriate reminder postcards, targeted telephone calls and intensive outreach and home visitation, showed a significant increase in children being UTD at 12 months. ${ }^{55}$ In the UK, a complex primary care focused intervention (developing a general practitioner (GP) network, financial incentives, better use of data and IT) significantly increased uptake of MMR coverage in a deprived, diverse community, although inequalities persisted in some smaller ethnic groups. ${ }^{56}$

The uncontrolled evaluation of an intervention to increase PCV coverage in Aboriginal infants in an Australian urban community (involving staff training, information materials, contact with parents, see online supplementary information, and stickers in health records) showed an increase. ${ }^{57}$ However, no statistical analysis was performed and coverage remained under the national Aboriginal average.

\section{Adolescent vaccinations}

Two Scottish studies reported on the HPV vaccine programme national roll-out among females aged 12 and 13, alongside a time-limited catch-up programme for females aged up to 18 (in school and in the community) and an accompanying media campaign. ${ }^{58} 59$ In the routine and catch-up programmes, uptake decreased by deprivation quintile for each subsequent dose, leading to a greater proportion of more deprived young people not completing the programme and thus increasing inequalities. Uptake was lowest in females who had left school and were vaccinated in the community (dose 1: 49\%, dose 3: 30\%), who were also more likely to be in a lower socioeconomic group. First-dose uptake was higher when regional health boards delivered the community catch-up clinic $(52.3 \%)$, compared to GP practices $(43.5 \%)$.

Two US studies used social marketing to increase HPV vaccine uptake in a large geographic area with an urban-rural divide, high ethnic diversity and a large low-income population: one in females aged 9-19 years and one in males aged 9-13 years. ${ }^{60}{ }^{61}$ In females, the approach overall had no differential effect. However, males who were unvaccinated in intervention counties were significantly more likely to be vaccinated after 6 months, with higher uptake among the non-Hispanic black population. However, males in intervention counties were also $24 \%$ less likely to receive a TDaP booster $(\mathrm{p} \leq 0.001)$.

A large before-and-after American study involving 17 federally qualified health centres (that act as a safety-net healthcare provider for underserved communities) evaluated the impact of a webinar targeting clinic coordinators, aiming to increase implementation of AFIX, a CDC-recommended list of practicebased interventions to increase vaccine uptake (including data collection and analysis, feedback to providers, incentive and specific staff). It found a statistically significant $1.1 \%$ increase in adolescents becoming UTD. ${ }^{62}$

Another American study evaluated a practice-based intervention (involving educational meetings, reminder/recall system usage, targeted reminders and incentive payments) alongside a telephone reminder to parents delivered through schools, which sought to reduce an urban/rural inequality. ${ }^{63}$ Results showed a significant increase in the uptake of first-dose HPV and Men4 vaccines (11-12 year olds) and HPV vaccine course completion (males aged 13-18 years). No significant differences found for other age bands or vaccine types.

\section{Influenza vaccine in CYP}

Two related American articles reported on the 'Four Pillars' intervention (increased service access, reminder/recall system, improved provider office systems and immunisation champions) to increase the uptake of seasonal influenza vaccine in CYP aged 6 months to 18 years. ${ }^{64}{ }^{65}$ Increases were seen in intervention 
Table 1 Population, intervention components and outcomes of the included studies considering complex interventions

\begin{tabular}{|c|c|c|c|c|c|c|c|c|c|c|c|c|c|c|c|c|c|}
\hline \multirow[b]{2}{*}{ References } & \multirow[b]{2}{*}{$\begin{array}{l}\text { First author } \\
\text { and year }\end{array}$} & \multirow[b]{2}{*}{ Population } & \multirow[b]{2}{*}{ Vaccine (s) } & \multirow[b]{2}{*}{ Inequality } & \multirow[b]{2}{*}{$\begin{array}{l}\text { Sample } \\
\text { (intervention) }\end{array}$} & \multirow[b]{2}{*}{$\begin{array}{l}\text { Intervention } \\
\text { name }\end{array}$} & \multicolumn{10}{|c|}{ Intervention components } & \multirow[b]{2}{*}{$\begin{array}{l}\text { Outcome (effect } \\
\text { measures and/or } \\
95 \% \mathrm{Cl} \text { ) }\end{array}$} \\
\hline & & & & & & & $\begin{array}{l}\text { Identification } \\
\text { or targeting } \\
\text { of CYP in risk } \\
\text { groups }\end{array}$ & $\begin{array}{l}\text { Promotional } \\
\text { materials } \\
\text { (eg, posters } \\
\text { or media } \\
\text { campaign) }\end{array}$ & $\begin{array}{l}\text { Education } \\
\text { children's } \\
\text { parents or } \\
\text { young } \\
\text { people } \\
\text { directly }\end{array}$ & $\begin{array}{l}\text { Patient } \\
\text { reminder/ } \\
\text { recall and/ } \\
\text { or tracking } \\
\text { and } \\
\text { surveillance }\end{array}$ & $\begin{array}{l}\text { Outreach } \\
\text { (eg, } \\
\text { home } \\
\text { visits) }\end{array}$ & $\begin{array}{l}\text { HCW training } \\
\text { (. allied } \\
\text { professionals) }\end{array}$ & $\begin{array}{l}\text { HCW } \\
\text { prompts }\end{array}$ & $\begin{array}{l}\text { Additional } \\
\text { services } \\
\text { (eg, } \\
\text { clinics) }\end{array}$ & $\begin{array}{l}\text { Standing } \\
\text { Orders* }\end{array}$ & $\begin{array}{l}\text { Community } \\
\text { involvement }\end{array}$ & \\
\hline 51 & $\begin{array}{l}\text { Findley et al, } \\
2008\end{array}$ & $\begin{array}{l}\text { Children 19- } \\
35 \text { months }\end{array}$ & Schedule & $\begin{array}{l}\text { Urban, } \\
\text { ethnicity, } \\
\text { low } \\
\text { income }\end{array}$ & 10857 (895) & Start right & - & Y & Y & $\mathrm{Y}$ & Y & Y & - & - & - & $\mathrm{Y}$ & $\begin{array}{l}11.1 \% \text { higher uptake } \\
\text { and } 53 \% \text { more likely to } \\
\text { be UTD ( } p<0.01, \text { no } C l)\end{array}$ \\
\hline 52 & $\begin{array}{l}\text { Fu et al, } \\
2012\end{array}$ & $\begin{array}{l}\text { Children } \\
\text { aged } \\
<24 \text { months }\end{array}$ & Schedule & $\begin{array}{l}\text { Urban, } \\
\text { ethnicity, } \\
\text { low } \\
\text { income }\end{array}$ & 3945 (1999) & - & - & Y & $Y$ & $\mathrm{Y}$ & - & Y & Y & Y & Y & - & $\begin{array}{l}16 \% \text { increase in uptake } \\
\text { to } 87 \% \text { ( }<<0.001 \text {, no } \\
\text { CI) }\end{array}$ \\
\hline 53 & $\begin{array}{l}\text { Suryadevara } \\
\text { et al, } 2013\end{array}$ & $C Y P<19$ years & Schedule & $\begin{array}{l}\text { Low } \\
\text { income/ } \\
\text { deprived }\end{array}$ & 1531 & - & Y & - & Y & $\mathrm{Y}$ & - & - & - & $\mathrm{Y}$ & - & $\mathrm{Y}$ & $\begin{array}{l}\text { Increase in coverage In } \\
\text { enrolled children from } \\
28 \% \text { to } 40 \%\end{array}$ \\
\hline 54 & $\begin{array}{l}\text { Isaac et al, } \\
2015\end{array}$ & $\begin{array}{l}\text { High-risk } \\
\text { infants } \\
\text { identified at } \\
\text { birth }\end{array}$ & Schedule & $\begin{array}{l}\text { Urban, } \\
\text { ethnicity, } \\
\text { low } \\
\text { income }\end{array}$ & 9746 (4562) & Family First & $\mathrm{Y}$ & - & $Y$ & - & $\mathrm{Y}$ & - & - & - & - & - & $\begin{array}{l}\text { Intervention risk ratio } \\
1.06 \text { for being UTD (CI } \\
1.03 \text { to } 1.08 \text { ). }\end{array}$ \\
\hline 55 & $\begin{array}{l}\text { Hambidge } \\
\text { et al, } 2009\end{array}$ & $\begin{array}{l}\text { New-born } \\
\text { infants until } \\
15 \text { months } \\
\text { old }\end{array}$ & Schedule & $\begin{array}{l}\text { Urban, } \\
\text { ethnicity, } \\
\text { low } \\
\text { income }\end{array}$ & 811 & - & Y & Y & Y & Y & Y & - & - & - & - & - & $\begin{array}{l}\text { Intervention OR of } 1.6 \\
\text { for being UTD (CI } 1.2 \text { to } \\
\text { 2.1) }\end{array}$ \\
\hline 56 & $\begin{array}{l}\text { Cockman } \\
\text { et al, } 2011\end{array}$ & $\begin{array}{l}\text { Children } \\
\text { aged } 2 \text { years }\end{array}$ & MMR & $\begin{array}{l}\text { Urban, } \\
\text { ethnicity, } \\
\text { low } \\
\text { income }\end{array}$ & 36 practices & - & $\mathrm{Y}$ & - & - & $\mathrm{Y}$ & - & Y & Y & $\mathrm{Y}$ & - & - & $\begin{array}{l}\text { A significant quarterly } \\
\text { coverage increase of } \\
1.86 \%\end{array}$ \\
\hline 57 & $\begin{array}{l}\text { Thomas } \\
\text { et al, } 2008\end{array}$ & $\begin{array}{l}\text { Aboriginal } \\
\text { infants }\end{array}$ & $\begin{array}{l}\text { 7-valent } \\
\text { PCV }\end{array}$ & Ethnicity & Ecological & - & $\mathrm{Y}$ & $Y$ & $\mathrm{Y}$ & - & $\mathrm{Y}$ & $\mathrm{Y}$ & $\mathrm{Y}$ & - & - & - & $\begin{array}{l}10 \% \text { increase in } \\
\text { coverage to } 50 \% \text { (no } \\
\text { statistical analysis) }\end{array}$ \\
\hline 58,59 & $\begin{array}{l}\text { Potts et al., } \\
\text { 2014; Sinka } \\
\text { et al, } 2013 .\end{array}$ & $\begin{array}{l}\text { Girls aged } \\
12-13, \text { with } \\
\text { catch-up for } \\
\text { under 18s. }\end{array}$ & HPV & Deprivation & 220000 & - & $\mathrm{Y}$ & Y & - & $\mathrm{Y}$ & - & Y & - & $\mathrm{Y}$ & - & - & $\begin{array}{l}\text { Equal uptake by } \\
\text { deprivation quintile for } \\
\text { first dose, with uptake } \\
\text { reducing for doses } 2 \\
\text { and } 3 \text {. }\end{array}$ \\
\hline 60 & $\begin{array}{l}\text { Cates et al, } \\
2011\end{array}$ & $\begin{array}{l}\text { Girls aged } \\
9-19\end{array}$ & HPV & $\begin{array}{l}\text { Urban, low } \\
\text { income, } \\
\text { ethnicity }\end{array}$ & $\begin{array}{l}100 \text { counties } \\
\text { (4 counties) }\end{array}$ & - & - & Y & - & - & - & - & $\mathrm{Y}$ & - & - & $\mathrm{Y}$ & $\begin{array}{l}\text { Different responses } \\
\text { across intervention } \\
\text { sites, no significant } \\
\text { difference overall. }\end{array}$ \\
\hline 61 & $\begin{array}{l}\text { Cates et al, } \\
2014\end{array}$ & $\begin{array}{l}\text { Men aged } \\
11-12\end{array}$ & HPV & $\begin{array}{l}\text { Urban, low } \\
\text { income, } \\
\text { ethnicity }\end{array}$ & $\begin{array}{l}28 \text { counties } \\
\text { (13 counties) }\end{array}$ & Protect Him & - & Y & - & - & - & Y & - & - & - & - & $\begin{array}{l}\text { Intervention } 34 \% \text { more } \\
\text { likely to be vaccinated } \\
\text { (p<0.002), with higher } \\
\text { uptake in non-Hispanic } \\
\text { black population. }\end{array}$ \\
\hline 62 & $\begin{array}{l}\text { Moss et al, } \\
2012\end{array}$ & $\begin{array}{l}\text { Adolescents } \\
\text { aged 12-17 }\end{array}$ & Schedule & $\begin{array}{l}\text { Urban, low } \\
\text { income, } \\
\text { ethnicity }\end{array}$ & $\begin{array}{l}17 \text { health } \\
\text { centres }\end{array}$ & $\begin{array}{l}\text { AFIX (by } \\
\text { proxy) }\end{array}$ & - & - & - & - & - & $\begin{array}{l}Y \text { (to increase } \\
\text { use of complex } \\
\text { intervention) }\end{array}$ & - & - & - & - & $\begin{array}{l}\text { Intervention } 1.1 \% \\
\text { increase in being UTD } \\
\text { across the schedule } \\
1 \text { month later (to } \\
32.2 \%, p=0.001 \text { ) }\end{array}$ \\
\hline
\end{tabular}


Table 1 Continued

\begin{tabular}{|c|c|c|c|c|c|c|c|c|c|c|c|c|c|c|c|c|c|}
\hline \multirow[b]{2}{*}{ References } & \multirow[b]{2}{*}{$\begin{array}{l}\text { First author } \\
\text { and year }\end{array}$} & \multirow[b]{2}{*}{ Population } & \multirow[b]{2}{*}{ Vaccine (s) } & \multirow[b]{2}{*}{ Inequality } & \multirow[b]{2}{*}{$\begin{array}{l}\text { Sample } \\
\text { (intervention) }\end{array}$} & \multirow[b]{2}{*}{$\begin{array}{l}\text { Intervention } \\
\text { name }\end{array}$} & \multicolumn{10}{|c|}{ Intervention components } & \multirow[b]{2}{*}{$\begin{array}{l}\text { Outcome (effect } \\
\text { measures and/or } \\
95 \% \mathrm{Cl} \text { ) }\end{array}$} \\
\hline & & & & & & & $\begin{array}{l}\text { Identification } \\
\text { or targeting } \\
\text { of CYP in risk } \\
\text { groups }\end{array}$ & $\begin{array}{l}\text { Promotional } \\
\text { materials } \\
\text { (eg, posters } \\
\text { or media } \\
\text { campaign) }\end{array}$ & $\begin{array}{l}\text { Education } \\
\text { children's } \\
\text { parents or } \\
\text { young } \\
\text { people } \\
\text { directly }\end{array}$ & $\begin{array}{l}\text { Patient } \\
\text { reminder/ } \\
\text { recall and/ } \\
\text { or tracking } \\
\text { and } \\
\text { surveillance }\end{array}$ & $\begin{array}{l}\text { Outreach } \\
\text { (eg, } \\
\text { home } \\
\text { visits) }\end{array}$ & $\begin{array}{l}\text { HCW training } \\
\text { (. allied } \\
\text { professionals) }\end{array}$ & $\begin{array}{l}\text { HCW } \\
\text { prompts }\end{array}$ & $\begin{array}{l}\text { Additional } \\
\text { services } \\
\text { (eg, } \\
\text { clinics) }\end{array}$ & $\begin{array}{l}\text { Standing } \\
\text { Orders }^{*}\end{array}$ & $\begin{array}{l}\text { Community } \\
\text { involvement }\end{array}$ & \\
\hline 63 & $\begin{array}{l}\text { Chung et al, } \\
2015\end{array}$ & $\begin{array}{l}\text { Adolescents } \\
\text { aged 11-18 }\end{array}$ & $\begin{array}{l}\text { Tdap, Men, } \\
\text { HPV }\end{array}$ & Urban/rural & $\begin{array}{l}5 \text { counties } \\
\text { (1 county, } 7 \\
\text { health centres) }\end{array}$ & - & - & $\mathrm{Y}$ & - & Y & - & Y & - & - & - & - & $\begin{array}{l}\text { Increase in the first } \\
\text { dose HPV in } 11-12 \text { year } \\
\text { olds (OR } 1.21, \mathrm{Cl} 1.01 \\
\text { to } 1.50) \text {, quad men (OR } \\
2.23, \mathrm{Cl} 1.7 \text { to } 2.9) \text { and } \\
\text { in } 13 \text { to } 19 \text { year olds } \\
\text { HPV vaccine completion } \\
\text { in men (OR } 1.45 \text {, Cl } \\
1.02 \text { to } 2.05) \text {. }\end{array}$ \\
\hline 64,65 & $\begin{array}{l}\text { Nowalk } \\
\text { et al, 2014; } \\
\text { Zimmerman } \\
\text { et al, } 2014\end{array}$ & $\begin{array}{l}\text { CYP aged } \\
6 \text { months to } \\
18 \text { years }\end{array}$ & Influenza & Ethnicity & 24 practices & Four Pillars & - & $\mathrm{Y}$ & - & $\mathrm{Y}$ & $\mathrm{Y}$ & $\mathrm{Y}$ & Y & $\mathrm{Y}$ & Y & - & $\begin{array}{l}\text { Greater increase in } \\
\text { uptake in intervention } \\
\text { group }(9.9 \% \text { vs } 4.2 \% \text { in } \\
\text { controls, } p<0.001) \text { and } \\
\text { higher in white children } \\
(16.7 \%, p<0.05)\end{array}$ \\
\hline 66 & $\begin{array}{l}\text { Logue et al } \\
2011\end{array}$ & $\begin{array}{l}\text { Children and } \\
\text { adults aged } \\
>6 \text { months }\end{array}$ & Influenza & $\begin{array}{l}\text { Urban, low } \\
\text { income, } \\
\text { ethnicity }\end{array}$ & 5061 & - & - & $\mathrm{Y}$ & - & - & - & $\mathrm{Y}$ & $Y$ & - & Y & - & $\begin{array}{l}\text { Increase in uptake in } \\
3-8 \text { year olds }(15 \% \text {, } \\
p<0.05) \text { and } 9-17 \text { year } \\
\text { olds (19\%, } p<0.05) \text {, but } \\
\text { not younger children. }\end{array}$ \\
\hline
\end{tabular}

*Standing orders allow non-prescribing health professionals to give medicines including vaccinations without a doctor's prescription in certain situations.

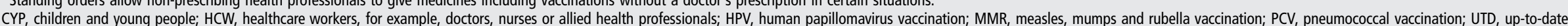
with all recommended vaccines for age. 
and control groups, with significantly greater increases in intervention areas and in white children, with a narrowing of the gap between ethnic groups.

One further uncontrolled before-and-after study in an urban, ethnically diverse family medicine centre examined a predominantly $\mathrm{HCW}$-focused intervention (involving policy change, standing orders, health record modification and information to patients) and showed increases in coverage in children aged between 3 and 18 (but not younger), with greater increases in African-Americans. ${ }^{66}$

\section{Outreach programmes}

One study conducted in parents of children from birth to 35 months evaluated the 'BIRTH PIP' intervention (parental education at birth followed by home visits) among 400 African-American mothers. ${ }^{67}$ When compared with the population, participants had significantly higher vaccination coverage (92\% vs $49 \%$ ), although there was significant loss to follow-up (50\% loss by 19 months). Another RCT evaluating an enhanced prenatal and postnatal home visitation programme among 530 low-income women versus regular community care found no difference in vaccination uptake. ${ }^{68}$ However, one other US study found that children living in deprived areas with an immunisation coordinator were less likely not to be UTD for age (adjusted OR 0.6) and that overall disparities had decreased between groups over the time of the programme. ${ }^{69}$

\section{Reminder/recall systems}

Table 2 describes the intervention type, sample size and study outcomes.

\section{Childhood vaccinations}

Two large American RCTs compared centralised systems versus Practice-based reminder/recall systems and concluded that centralised systems increased likelihood of children becoming UTD for age. ${ }^{70} 71$

A UK before-and-after study evaluating an escalating reminder/recall system, including letters and home visits, in an ethnically diverse, urban population, found that uptake was stable in intervention areas, but decreased in non-intervention areas. $^{72}$ In the USA, a large RCT targeting non-UTD children aged $<20$ months with a postal reminder or recall notices found no coverage difference in younger children ( 7 or 12 months), but a significant increase at 19 months. ${ }^{73}$ The hypothesis offered was that younger children would be attending services more regularly and thus have higher uptake, whereas older children might not and thus be more responsive to reminders. Of two Canadian studies examining MMR coverage in deprived areas, one controlled before-and-after study found that telephone reminders increased MMR uptake in children not UTD at 24 months $;{ }^{74}$ however, the other non-controlled time series found increases in intervention (targeted phone, mail and outreach) and non-intervention sites, with no decrease in socioeconomic disparities. ${ }^{75}$

The Text4Health study evaluated the effect of sending text messages to parents in an American, urban, low-income population, prompting them to have their children aged 7-22 months vaccinated with $\mathrm{Hib}^{76}{ }^{76}$ It found a non-significant uptake difference after 2 weeks. An RCT undertaken in an urban, lowincome minority ethnic population in the USA randomised participants to receive text-message reminders to schedule an appointment and/or reminders of the appointment details, or usual care to increase MMR vaccine uptake at 13 months. ${ }^{77}$ There was no difference in uptake between the arms, except in children who did not have a vaccination appointment booked and who received scheduling and appointment reminders.

An uncontrolled before-and-after study evaluating an immunisation reminder calendar given to parents of Aboriginal children in Australia showed timeliness for being UTD for vaccines increased, once significant outliers were excluded. ${ }^{78}$

\section{Adolescent vaccinations}

Two studies examined the use of repeated SMS reminders. The Text4Health study found significant increases in MenC and TDaP vaccine uptake among 11-18 year olds in the intervention arm. ${ }^{76}$ Another non-randomised trial looked at second and third doses of HPV vaccine in urban adolescent females and found that intervention individuals were significantly more likely to receive doses on time. ${ }^{79}$

Two studies examined different reminder/recall media. One RCT evaluated a tiered protocol with progressively more intensive reminder/recall and outreach dependent on continued lack of vaccine uptake. ${ }^{80}$ It found that the intervention was associated with becoming UTD for each vaccine and was more successful among females and black and Hispanic adolescents. An uncontrolled study targeting ethnically and socioeconomically diverse parents of adolescents not UTD with a variety of reminders over 12 months showed that $25.5 \%$ participants received one missing vaccine. ${ }^{81}$

An RCT comparing uptake of Men4 and TDaP in adolescents not UTD using phone reminders only to parents, versus parents and adolescents, found significantly higher uptake in the parent and adolescent reminder group. ${ }^{82} \mathrm{~A}$ non-RCT compared postal, email or SMS reminders for adolescent vaccination on the basis of parental preference and found that those who signed up were more likely to become UTD, irrespective of the method of reminder. ${ }^{83}$

A UK study evaluated giving a $£ 40$ incentive alongside a reminder/recall system and found significantly increased odds of completing the HPV vaccine course, irrespective of deprivation levels. $^{84}$

\section{Influenza vaccination in CYP}

Three American RCTs examined the effect of SMS reminders targeted at low-income, minority ethnic parents on influenza vaccine uptake. Parents of CYP aged 6 months to 18 years receiving 5 weekly community-developed educational and clinic reminder text messages significantly increased uptake although overall levels remained low. ${ }^{85}$ When comparing educational and conventional SMSs with postal reminders targeted to parents of children aged 6 months to 8 years, those receiving the educational SMS had higher second-dose influenza vaccine uptake. ${ }^{86}$ Another study compared interactive SMSs with educational ones, compared to usual care, in CYP aged 6 months to 17 years unvaccinated for influenza late in the season. ${ }^{87}$ Children of parents who received an interactive SMS were slightly more likely to be vaccinated. However, only $1 \%$ parents used the interactive feature.

\section{Reminder systems targeted at HCWs}

A large retrospective before-and-after study in the USA examined the effect of a vaccine alert placed within electronic health records of females aged $9-26 .{ }^{88}$ The intervention prompted cohort had higher initiation than the unprompted control cohort $(35 \%$ vs $21.3 \%)$, with higher initiation rates seen in African-Americans. Another American RCT examined the effect of HCW prompts on adolescent vaccine uptake in a diverse population, but found no difference in uptake between intervention and control practices. ${ }^{89}$ 
Table 2 Population, intervention components and outcomes of the included studies considering reminder/recall interventions targeted at patients or clients.

\begin{tabular}{|c|c|c|c|c|c|c|c|c|c|c|c|c|}
\hline \multirow[b]{2}{*}{ References } & \multirow[b]{2}{*}{$\begin{array}{l}\text { First author } \\
\text { and year }\end{array}$} & \multirow[b]{2}{*}{ Population } & \multirow[b]{2}{*}{ Vaccine(s) } & \multirow[b]{2}{*}{ Inequality } & \multirow[b]{2}{*}{$\begin{array}{l}\text { Sample Size } \\
\text { (intervention) }\end{array}$} & \multicolumn{5}{|c|}{ Intervention components } & \multirow[b]{2}{*}{ Intervention description } & \multirow[b]{2}{*}{$\begin{array}{l}\text { Outcome (effect measures } \\
\text { and/or } 95 \% \mathrm{Cl} \text { ) }\end{array}$} \\
\hline & & & & & & $\begin{array}{l}\text { Identification } \\
\text { of those not } \\
\text { UTD* }\end{array}$ & $\begin{array}{l}\text { Text } \\
\text { message } \\
(s)\end{array}$ & $\begin{array}{l}\text { Letter } \\
\text { (s) to } \\
\text { home }\end{array}$ & $\begin{array}{l}\text { Telephone } \\
\text { call(s) }\end{array}$ & $\begin{array}{l}\text { Outreach } \\
\text { (eg, home } \\
\text { visit) }\end{array}$ & & \\
\hline 70 & $\begin{array}{l}\text { Kempe et al, } \\
2013\end{array}$ & $\begin{array}{l}\text { Children aged } \\
19-35 \text { months }\end{array}$ & Schedule & $\begin{array}{l}\text { Urban/rural, } \\
\text { not UTD }\end{array}$ & 55173 & Y & - & Y & - & - & $\begin{array}{l}\text { Practices participating } \\
\text { received financial } \\
\text { assistance. Up to three } \\
\text { notifications sent. }\end{array}$ & $\begin{array}{l}\text { Increase in chances of becoming } \\
\text { UTD if population based reminder } \\
\text { system used (relative risk } 1.23, \mathrm{Cl} \\
1.10 \text { to } 1.37 \text { ) }\end{array}$ \\
\hline 71 & $\begin{array}{l}\text { Kempe et al, } \\
2015\end{array}$ & $\begin{array}{l}\text { Children aged } \\
19-35 \text { months }\end{array}$ & Schedule & $\begin{array}{l}\text { Urban/rural, } \\
\text { not UTD }\end{array}$ & 18235 & Y & & Y & Y & - & $\begin{array}{l}\text { Centralised reminder } \\
\text { system involved either } \\
\text { telephone and letters or } \\
\text { letters alone. The } \\
\text { practice-based system was } \\
\text { variable at practice level, } \\
\text { but involved calls or } \\
\text { letters or both. }\end{array}$ & $\begin{array}{l}\text { Increase in children being UTD by } \\
2.5 \%(p<0.001) \text { using the } \\
\text { centralised system (adj OR } 1.31 \text {, } \\
\text { Cl } 1.16 \text { to } 1.48)\end{array}$ \\
\hline 72 & $\begin{array}{l}\text { Atchison } \\
\text { et al, } 2013\end{array}$ & $\begin{array}{l}\text { Children under } \\
5 \text { years }\end{array}$ & Schedule & $\begin{array}{l}\text { Urban, low } \\
\text { income, } \\
\text { ethnicity }\end{array}$ & 32 practices & Y & - & Y & Y & Y & $\begin{array}{l}\text { Escalating intervention } \\
\text { comprising two letters, } \\
\text { followed by a telephone } \\
\text { call or home visit if no } \\
\text { response. }\end{array}$ & $\begin{array}{l}\text { Significant increase in proportion } \\
\text { UTD in the intervention group, } \\
\text { but as a result of unexplained } \\
\text { decreases in the non-intervention } \\
\text { group. }\end{array}$ \\
\hline 73 & $\begin{array}{l}\text { Dombkowski } \\
\text { et al, } 2014\end{array}$ & $\begin{array}{l}\text { Children under } \\
20 \text { months }\end{array}$ & Schedule & $\begin{array}{l}\text { Urban, not } \\
\text { UTD }\end{array}$ & 10175 & Y & - & Y & - & - & $\begin{array}{l}\text { Recall notices issued at } 7 \\
\text { and } 19 \text { months, with a } \\
\text { reminder notice at } \\
12 \text { months. }\end{array}$ & $\begin{array}{l}\text { No difference in children at } 7 \text { or } \\
12 \text { months, but a significant } \\
\text { difference of } 7 \%(p<0.0001) \mid \text { at } \\
19 \text { months. }\end{array}$ \\
\hline 74 & $\begin{array}{l}\text { Lemstra et al, } \\
2011\end{array}$ & $\begin{array}{l}\text { Children not } \\
\text { UTD with } \\
\text { MMR at } \\
24 \text { months }\end{array}$ & MMR & $\begin{array}{l}\text { Deprivation, } \\
\text { low income }\end{array}$ & 629 & Y & - & - & Y & Y & $\begin{array}{l}\text { Home visits targeted as a } \\
\text { separate intervention in } \\
\text { low-income areas. }\end{array}$ & $\begin{array}{l}\text { Significant increase in intervention } \\
\text { areas (rate ratio } 1.10, \mathrm{Cl} 1.08 \text { to } \\
\text { 1.12). Increase in home visit } \\
\text { areas, but not significant due to } \\
\text { small numbers. }\end{array}$ \\
\hline 75 & $\begin{array}{l}\text { Cushon et al, } \\
2012\end{array}$ & $\begin{array}{l}\text { Children aged } \\
14-20 \text { months }\end{array}$ & MMR & $\begin{array}{l}\text { Deprivation, } \\
\text { low-income }\end{array}$ & 24540 & Y & - & Y & Y & Y & $\begin{array}{l}\text { Identification of children } \\
\text { not UTD, five telephone } \\
\text { calls, letter home and } \\
\text { then home visitation. }\end{array}$ & $\begin{array}{l}\text { Increases observed in across all } \\
\text { study sites, including low-income } \\
\text { areas. No significant difference } \\
\text { observed in intervention sites, } \\
\text { disparities remained. }\end{array}$ \\
\hline 76 & $\begin{array}{l}\text { Stockwell } \\
\text { et al, } 2012 \mathrm{~A}\end{array}$ & $\begin{array}{l}\text { Children aged } \\
7-22 \text { months }\end{array}$ & Hib & $\begin{array}{l}\text { Urban, low } \\
\text { income }\end{array}$ & 174 & Y & Y & Y & - & - & $\begin{array}{l}\text { Repeated reminders } \\
\text { delivered five times until } \\
\text { vaccination status } \\
\text { registered as UTD. }\end{array}$ & $\begin{array}{l}\text { Non-significant difference, } \\
\text { possibly due to small sample size } \\
(n=174)\end{array}$ \\
\hline 77 & $\begin{array}{l}\text { Hofstetter } \\
\text { et al, } 2015 \mathrm{~A}\end{array}$ & $\begin{array}{l}\text { Children aged } \\
9.5- \\
10.5 \text { months. }\end{array}$ & MMR & $\begin{array}{l}\text { Urban, low } \\
\text { income, } \\
\text { ethnicity }\end{array}$ & 2054 & - & Y & - & - & - & $\begin{array}{l}\text { Participants either } \\
\text { received reminders to } \\
\text { schedule a vaccination } \\
\text { appointment and then an } \\
\text { appointment reminder; } \\
\text { appointment reminder } \\
\text { only; or usual care. }\end{array}$ & $\begin{array}{l}\text { No difference between arms } \\
\text { except in children with no } \\
\text { vaccination appointment booked, } \\
\text { who received scheduling and } \\
\text { appointment reminders (relative } \\
\text { risk ratio } 1.11, \mathrm{Cl} 1.00 \text { to } 1.24 \text { ) }\end{array}$ \\
\hline 78 & $\begin{array}{l}\text { Abbott et al, } \\
2013\end{array}$ & $\begin{array}{l}\text { Aboriginal } \\
\text { children from } \\
\text { birth to } \\
20 \text { months }\end{array}$ & Schedule & Ethnicity & 505 & - & - & - & - & - & $\begin{array}{l}\text { Reminder calendar given } \\
\text { to parents }\end{array}$ & $\begin{array}{l}\text { Significant increase in } \\
\text { vaccinations being given on time, } \\
\text { once outliers were excluded. }\end{array}$ \\
\hline
\end{tabular}




\begin{tabular}{|c|c|c|c|c|c|c|c|c|c|c|c|c|}
\hline \multirow[b]{2}{*}{ References } & \multirow[b]{2}{*}{$\begin{array}{l}\text { First author } \\
\text { and year }\end{array}$} & \multirow[b]{2}{*}{ Population } & \multirow[b]{2}{*}{ Vaccine(s) } & \multirow[b]{2}{*}{ Inequality } & \multirow[b]{2}{*}{$\begin{array}{l}\text { Sample Size } \\
\text { (intervention) }\end{array}$} & \multicolumn{5}{|c|}{ Intervention components } & \multirow[b]{2}{*}{ Intervention description } & \multirow[b]{2}{*}{$\begin{array}{l}\text { Outcome (effect measures } \\
\text { and/or } 95 \% \mathrm{Cl} \text { ) }\end{array}$} \\
\hline & & & & & & $\begin{array}{l}\text { Identification } \\
\text { of those not } \\
\text { UTD* }\end{array}$ & $\begin{array}{l}\text { Text } \\
\text { message } \\
(\mathrm{s})\end{array}$ & $\begin{array}{l}\text { Letter } \\
\text { (s) to } \\
\text { home }\end{array}$ & $\begin{array}{l}\text { Telephone } \\
\text { call(s) }\end{array}$ & $\begin{array}{l}\text { Outreach } \\
\text { (eg, home } \\
\text { visit) }\end{array}$ & & \\
\hline 76 & $\begin{array}{l}\text { Stockwell } \\
\text { et al, } 2012 \mathrm{~A}\end{array}$ & $\begin{array}{l}\text { Adolescents } \\
\text { aged 11-18 }\end{array}$ & Td, Men4 & $\begin{array}{l}\text { Urban, low } \\
\text { income, } \\
\text { ethnicity }\end{array}$ & 361 (195) & Y & Y & - & - & - & $\begin{array}{l}\text { Repeated reminders } \\
\text { delivered five times until } \\
\text { vaccination status } \\
\text { registered as UTD. }\end{array}$ & $\begin{array}{l}\text { Significantly more adolescents in } \\
\text { the intervention arm received } \\
\text { missing vaccines at } 4,12 \text { and } \\
24 \text { weeks (eg, at } 12 \text { weeks } 26.7 \% \\
\text { vs } 13.9 \% \text { in controls, } 12.8 \% \\
\text { difference } \mathrm{Cl} 4.7 \% \text { to } 20.9 \% \text {, } \\
\mathrm{p}=0.003 \text { ). }\end{array}$ \\
\hline 79 & $\begin{array}{l}\text { Kharbanda } \\
\text { et al, } 2011\end{array}$ & $\begin{array}{l}\text { Adolescent } \\
\text { girls aged } \\
9-20\end{array}$ & $\begin{array}{l}\text { HPV (doses } \\
2 \text { and 3) }\end{array}$ & Urban & 124 & Y & Y & - & - & - & $\begin{array}{l}\text { Up to three weekly } \\
\text { reminders that child due } \\
\text { for an HPV dose. }\end{array}$ & $\begin{array}{l}\text { Intervention individuals were } \\
\text { more likely than controls, } \\
\text { contemporaneous (adjusted OR } \\
2.03, \mathrm{Cl} 1.29 \text { to } 3.22 \mathrm{p}=0.003 \text { ) } \\
\text { and historical (AOR } 1.83, \mathrm{Cl} 1.23 \\
\text { to } 2.71, \mathrm{p}=0.002 \text { ) to receive next } \\
\text { HPV dose on time. }\end{array}$ \\
\hline 80 & $\begin{array}{l}\text { Szilagyi et al, } \\
2011\end{array}$ & $\begin{array}{l}\text { Adolescents } \\
\text { aged 11-15 }\end{array}$ & $\begin{array}{l}\text { Pertussis, } \\
\text { Men, HPV }\end{array}$ & Ethnicity & 7546 & Y & - & Y & $\mathrm{Y}$ & Y & $\begin{array}{l}\text { Reminder/recall and home } \\
\text { visits undertaken by } \\
\text { specialist vaccine system } \\
\text { navigators. }\end{array}$ & $\begin{array}{l}\text { Becoming UTD for each vaccine } \\
\text { was } 12 \% \text { to } 16 \% \text { higher in the } \\
\text { intervention group }(p<0.001) \text {, } \\
\text { with } 71 \% \text { of the intervention } \\
\text { group having received a reminder } \\
\text { and } 12 \% \text { a home visit. }\end{array}$ \\
\hline 81 & $\begin{array}{l}\text { Bar-Shain } \\
\text { et al, } 2015\end{array}$ & $\begin{array}{l}\text { Adolescents } \\
\text { aged } 11-18\end{array}$ & $\begin{array}{l}\text { HPV, MenC, } \\
\text { Tdap }\end{array}$ & $\begin{array}{l}\text { Deprivation, } \\
\text { ethnicity }\end{array}$ & 3393 & Y & Y & Y & $\mathrm{Y}$ & - & $\begin{array}{l}\text { Depending on availability } \\
\text { of contact information } \\
\text { either an email, text } \\
\text { message or postcard was } \\
\text { sent, repeated every } \\
2 \text { months for up to } \\
12 \text { months until UTD }\end{array}$ & $\begin{array}{l}25.5 \% \text { of adolescents in the study } \\
\text { received at least one missing } \\
\text { vaccine and response to the } \\
\text { messaging reduced with each } \\
\text { round. There were no differential } \\
\text { effects by age, gender, insurance } \\
\text { status or ethnicity. }\end{array}$ \\
\hline 82 & $\begin{array}{l}\text { Brigham et al, } \\
2012\end{array}$ & $\begin{array}{l}\text { Adolescents } \\
\text { aged 13-17. }\end{array}$ & Tdap, Men4 & $\begin{array}{l}\text { Urban, not } \\
\text { UTD }\end{array}$ & 424 & Y & - & - & Y & - & $\begin{array}{l}\text { Compared calls to parents } \\
\text { to calls to parents and } \\
\text { adolescents. }\end{array}$ & $\begin{array}{l}\text { Higher uptake in the parent and } \\
\text { adolescent reminder group (adj } \\
\text { OR } 2.27 \text {,) however with a large CI } \\
\text { (CI } 1.00 \text { to } 5.18 \text { ) }\end{array}$ \\
\hline 83 & $\begin{array}{l}\text { Morris et al, } \\
2015\end{array}$ & $\begin{array}{l}\text { Adolescents } \\
\text { aged 11-17. }\end{array}$ & $\begin{array}{l}\text { HPV, Men4, } \\
\text { Tdap, Var }\end{array}$ & $\begin{array}{l}\text { Urban, } \\
\text { deprivation }\end{array}$ & 5050 & Y & Y & Y & Y & - & $\begin{array}{l}\text { Series of } 3 \text { batches of } \\
\text { reminders over } 6 \text { months, } \\
\text { based on parents' choice } \\
\text { of message medium. }\end{array}$ & $\begin{array}{l}\text { Those who signed up for any } \\
\text { method of reminder were more } \\
\text { likely to become UTD than those } \\
\text { who only received an enrolment } \\
\text { phone call ( } 24.6 \% \text { vs } 12.4 \% \text {, } \\
\text { p }<0.001 \text { ). }\end{array}$ \\
\hline 84 & $\begin{array}{l}\text { Mantzari } \\
\text { et al, } 2015\end{array}$ & $\begin{array}{l}\text { Adolescent } \\
\text { girls aged } 17- \\
18\end{array}$ & $\begin{array}{l}\text { HPV } \\
\text { initiation } \\
\text { and } \\
\text { completion }\end{array}$ & Deprivation & 1000 & Y & Y & Y & - & - & $\begin{array}{l}\text { Letter with incentive offer } \\
\text { sent to house, followed } \\
\text { by series of text messages } \\
\text { between the second and } \\
\text { third dose. }\end{array}$ & $\begin{array}{l}\text { Increased uptake of the first dose } \\
\text { in intervention individuals (OR } \\
1.63 \text { ). However, no differential } \\
\text { impact by deprivation. }\end{array}$ \\
\hline
\end{tabular}




\section{Table 2 Continued}

\begin{tabular}{|c|c|c|c|c|c|c|c|c|c|c|c|c|}
\hline \multirow[b]{2}{*}{ References } & \multirow[b]{2}{*}{$\begin{array}{l}\text { First author } \\
\text { and year }\end{array}$} & \multirow[b]{2}{*}{ Population } & \multirow[b]{2}{*}{ Vaccine(s) } & \multirow[b]{2}{*}{ Inequality } & \multirow[b]{2}{*}{$\begin{array}{l}\text { Sample Size } \\
\text { (intervention) }\end{array}$} & \multicolumn{5}{|c|}{ Intervention components } & \multirow[b]{2}{*}{ Intervention description } & \multirow[b]{2}{*}{$\begin{array}{l}\text { Outcome (effect measures } \\
\text { and/or } 95 \% \mathrm{Cl} \text { ) }\end{array}$} \\
\hline & & & & & & $\begin{array}{l}\text { Identification } \\
\text { of those not } \\
\text { UTD* }\end{array}$ & $\begin{array}{l}\text { Text } \\
\text { message } \\
\text { (s) }\end{array}$ & $\begin{array}{l}\text { Letter } \\
\text { (s) to } \\
\text { home }\end{array}$ & $\begin{array}{l}\text { Telephone } \\
\text { call(s) }\end{array}$ & $\begin{array}{l}\text { Outreach } \\
\text { (eg, home } \\
\text { visit) }\end{array}$ & & \\
\hline 85 & $\begin{array}{l}\text { Stockwell } \\
\text { et al, } 2012 \text { B }\end{array}$ & $\begin{array}{l}\text { CYP aged } \\
6 \text { months to } \\
18 \text { years. }\end{array}$ & Influenza & $\begin{array}{l}\text { Low income, } \\
\text { ethnicity }\end{array}$ & 9213 & - & Y & & & & $\begin{array}{l}\text { Series of five text } \\
\text { messages with } \\
\text { educational information. }\end{array}$ & $\begin{array}{l}\text { Higher proportion of CYP } \\
\text { vaccinated in the intervention } \\
\text { group ( } 3.7 \% \text { increase, CI } 1.5 \% \text { to } \\
5.9 \%, \mathrm{p}=0.001 \text {; relative risk ratio } \\
1.09, \mathrm{Cl} 1.04 \text { to } 1.15) \text {, although } \\
\text { overall rates remained low at } \\
\text { around } 40 \%\end{array}$ \\
\hline 86 & $\begin{array}{l}\text { Stockwell } \\
\text { et al, } 2015\end{array}$ & $\begin{array}{l}\text { Children } \\
6 \text { months to } 8 \\
\text { years }\end{array}$ & Influenza & $\begin{array}{l}\text { Low income, } \\
\text { ethnicity }\end{array}$ & 660 & - & Y & Y & - & - & $\begin{array}{l}\text { Three arms: education vs } \\
\text { conventional text plus } \\
\text { letter, and usual care } \\
\text { (letter only) control. }\end{array}$ & $\begin{array}{l}\text { Children in the educational group } \\
\text { were significantly more likely to } \\
\text { receive the second influenza dose } \\
(72.7 \%, p=0.003) \text { compared to } \\
\text { conventional text }(66.7 \%) \text { and } \\
\text { postal reminder only }(57.1 \%) \text {. }\end{array}$ \\
\hline 87 & $\begin{array}{l}\text { Hofstetter } \\
\text { et al, } 2015 \text { B }\end{array}$ & $\begin{array}{l}\text { CYP } 6 \text { months } \\
\text { to } 17 \text { years }\end{array}$ & Influenza & $\begin{array}{l}\text { Low income, } \\
\text { ethnicity }\end{array}$ & 5462 & Y & Y & Y & - & - & $\begin{array}{l}\text { Three arms: interactive } \\
\text { educational message vs } \\
\text { educational text vs usual } \\
\text { care control. }\end{array}$ & $\begin{array}{l}\text { The interactive component of the } \\
\text { messages had low uptake ( } 1.0 \% \\
\text { using the service); however, } \\
\text { slightly more in this arm were } \\
\text { vaccinated than those who } \\
\text { received the education only text } \\
(38.5 \% \text { vs } 35.3 \% \text {, relative risk } \\
\text { ratio } 1.09 \mathrm{Cl} 1.00 \text { to } 1.19 \text {, } \\
p=0.04)\end{array}$ \\
\hline
\end{tabular}

CYP, children and young people; HCW, healthcare workers, for example, doctors, nurses or allied health professionals; Hib, Haemophilus influenzae group b vaccination; HPV, human papillomavirus vaccination; Men4, quadrivalent meningococcal vaccination (A, C, W and Y); MenC, meningococcal group c vaccination; MMR, measles, mumps and rubella vaccination; Td, tetanus and diphtheria vaccination; Tdap, tetanus, diphtheria, pertussis vaccination; UTD, up-to-date with all recommended vaccines for age; Var, varicella vaccination. 


\section{Computer-based interventions}

Two studies examining computer-based interventions found no effect on vaccine uptake. An RCT evaluating an intervention targeting African-American females to increase HPV vaccine uptake ('Girls on Guard') found that only 12\% of 216 participants initiated the vaccine course, with equal numbers in intervention and control groups. $^{90}$ Another randomised study examined a computer-based health message intervention delivered in school-based clinics in a population of ethnically diverse parents of non-HPV vaccinated children $(n=445)$ and found that rhetorical questioning message prompts increased vaccination intention, but not uptake. ${ }^{91}$

\section{DISCUSSION}

The impact of socioeconomic context, including deprivation, ethnicity or geography, on health outcomes has been well documented $^{92}$ and is equally true of vaccine programmes. ${ }^{93}$ Presented here is the evidence of effectiveness for interventions to reduce the resulting inequalities in vaccination coverage. Multicomponent locally designed interventions demonstrated the best evidence in children and adolescents in the short term. These interventions are designed for a specific context and population, so may not be transferable to other settings. The 2009 NICE guidance recommended home visiting as a possibly cost-effective intervention, which is partially supported by this evidence. All nine interventions that included a home visit component showed some evidence of effectiveness. 515455576472747581 Although two of three studies considering outreach interventions alone were not effective, they were either small or had significant loss to follow-up. ${ }^{67} 68$ The three studies using escalating intervention intensity seemed particularly effective, which is consistent with the previous review. ${ }^{557280}$ This may be a cost-effective way of incorporating home visiting into a programme. Social marketing interventions show mixed evidence, but could be a promising approach in adolescents. ${ }^{60} 61$ No studies provided good long-term evidence of sustained uptake.

The evidence around reminder/recall systems continues to evolve. In the USA, centralised reminder/recall systems worked better than practice-based ones; however, this may be specific to the American health system. Evidence of effectiveness of textmessage reminders in reducing inequalities remains limited. The type of messages received may impact vaccine uptake, particularly if educational or interactive messages are used. However, more research is required to confirm this effect. A recent systematic review of 'new media' to improve vaccine uptake found evidence of effectiveness for SMS reminders, but also considered a wide variety of other interventions such as mobile phone apps and the use of social media. ${ }^{44}$ We did not identify any studies that used new media to reduce vaccine uptake inequalities, and this could form potentially useful future work. The two studies examining computer-based behaviour change interventions found no evidence of effectiveness.

There is some evidence for postal and telephone reminders in children and adolescents, although heterogeneity of interventions precludes from drawing firm conclusions. Choosing the reminder method and including adolescents alongside parents for reminders possibly improved effectiveness. ${ }^{82} 83$ A recent systematic review found that targeting postal and telephone reminders to parents was most effective at increasing early childhood vaccination. $^{37}$
We found mixed evidence for HCW-focused reminders, which adds to the previous review's two positive studies. The evidence for client-side financial incentives was mixed in the previous review, and we found one additional study that showed an increase in adolescent HPV uptake. However, a recent systematic review found no effect of incentives on vaccine uptake in children. ${ }^{30}$

Two studies noted intervention effectiveness in older children, but not younger children. ${ }^{66} 73$ This may be because younger children are more likely to seek routine healthcare and should be a consideration when targeting interventions.

\section{Tackling inequalities}

Most interventions did not specifically target inequalities, but instead delivered interventions in low-uptake populations and focused on CYP not UTD for age.

Several interventions reported differential effects by ethnicity, including Aboriginal infants in Australia, ${ }^{57} 78$ White children $^{64-66}$ and non-Hispanic black adolescents ${ }^{65}$ as well as black and Hispanic adolescents in the USA. ${ }^{61} 80$ These interventions are very context and population specific, and further work is required to develop the evidence base for interventions targeting specific ethnic groups or other characteristics associated with vaccine uptake inequality such as deprivation.

\section{Limitations}

Studies were mainly from the USA, with some from the UK, Canada and Australia. We found none from other European countries. This paucity mirrors the low number of European studies in the previous review. This may be related to the English language restriction or due to the unavailability of certain types of data (eg, it is illegal to collect data on ethnicity in France). We did not consider cost-effectiveness of interventions, although this was reported in some studies, due to challenges in comparing results between different health systems. Vaccine hesitancy was not considered for two reasons: first, a separate systematic review exists on interventions to reduce hesitancy and ${ }^{40}$ second, very few inclusions in that review or this paper measured uptake or coverage as an outcome. There are likely to be opportunities to incorporate evidence-based interventions to reduce hesitancy more explicitly within interventions to reduce inequalities in uptake between different groups.

\section{Recommendations}

- Locally designed, multicomponent interventions have the strongest evidence for increasing vaccine uptake, particularly in urban, ethnically diverse, low-income or deprived population.

- Some evidence is emerging relating to the use of text messages and other types of reminder/recall systems, particularly in adolescents, and should be considered.

- Interventions that increase in intensity targeting persistent non-responders have some evidence of effectiveness and may be more cost-effective than other interventions, such as universal home visiting alone.

- Further research should be conducted: in the UK and Europe, focusing on reducing specific inequalities, such as by the ethnic or religious group and on smartphone technology to increase vaccine uptake. 


\section{What is already known on this subject}

In high-income countries, substantial differences exist in vaccine uptake relating to socioeconomic status, gender, ethnic group, geographic location and religious belief. A previous systematic review from 2009 concluded that the evidence was promising for outreach programmes, mixed for reminder/recall systems and information provision and limited for text messages and service delivery interventions.

\section{What this study adds}

This study updates the systematic review to 2015 and concludes that locally designed, multicomponent interventions have evidence of effectiveness in urban, ethnically diverse, deprived populations. There is some evidence emerging for text-message reminders, particularly in adolescents, but that other types of technology have not yet been evaluated.

\section{Twitter Follow Tim Crocker-Buque at @drtimcb}

Acknowledgements The authors thank Dr Mary Ramsay at Public Health England for her advice and support during the development of this work.

Contributors SM-J conceived the study with ME. TC-B undertook the literature search. TC-B and SM-J reviewed the abstracts and agreed inclusions. TC-B extracted the relevant data and produced an initial draft of the paper, which was reviewed and edited by SM-J and ME.

Funding The research was funded by the National Institute for Health Research Health Protection Research Unit (NIHR HPRU) in Immunisation at the London School of Hygiene and Tropical Medicine in partnership with Public Health England (PHE).

Disclaimer The views expressed are those of the authors and not necessarily those of the NIHR, the Department of Health or PHE.

\section{Competing interests None declared.}

Provenance and peer review Not commissioned; externally peer reviewed.

Open Access This is an Open Access article distributed in accordance with the terms of the Creative Commons Attribution (CC BY 4.0) license, which permits others to distribute, remix, adapt and build upon this work, for commercial use, provided the original work is properly cited. See: http://creativecommons.org/licenses/ by $/ 4.0 /$

\section{REFERENCES}

1 Polonijo AN, Carpiano RM. Social inequalities in adolescent human papillomavirus (HPV) vaccination: a test of fundamental cause theory. Soc Sci Med 2013;82:115-25.

2 Baker D, Garrow A, Shiels C, et al. Inequalities in immunisation and breast feeding in an ethnically diverse urban area: cross-sectional study in Manchester, UK. J Epidemiol Community Health 2011;65:346-52.

3 Coupland $C$, Harcourt $S$, Vinogradova $Y$, et al. Inequalities in uptake of influenza vaccine by deprivation and risk group: time trends analysis. Vaccine 2007;25:7363-71.

4 Endrich MM, Blank PR, Szucs TD. Influenza vaccination uptake and socioeconomic determinants in 11 European countries. Vaccine 2009;27:4018-24

5 Fisher $\mathrm{H}$, Audrey S, Mytton JA, et al. Examining inequalities in the uptake of the school-based HPV vaccination programme in England: a retrospective cohort study. J Public Health 2014;36:36-45.

6 Friederichs V, Cameron JC, Robertson C, et al. Impact of adverse publicity on MMR vaccine uptake: a population based analysis of vaccine uptake records for one million children, born 1987-2004. Arch Dis Child 2006;91:465-8.

7 Galarce EM, Minsky S, Viswanath K. Socioeconomic status, demographics, beliefs and $A(H 1 N 1)$ vaccine uptake in the United States. Vaccine 2011;29:5284-9.

8 Hawker Jl, Olowokure B, Wood AL, et al. Widening inequalities in MMR vaccine uptake rates among ethnic groups in an urban area of the UK during a period of vaccine controversy (1994-2000). Vaccine 2007;25:7516-19.
9 Health and Social Care Information Centre. NHS Immunisation Statistics: England 2013-2014. London, UK: HSCIC, 2014:1-123.

10 Hill HA, Elam-Evans LD, Yankey D, et al. National, state, and selected local area vaccination coverage among children aged 19-35 months-United States, 2014. MMWR Morb Mortal Wkly Rep 2015;64:889-96.

11 Kumar VM, Whynes DK. Explaining variation in the uptake of HPV vaccination in England. BMC Public Health 2011;11:172.

12 Mixer RE, Jamrozik K, Newsom D. Ethnicity as a correlate of the uptake of the first dose of mumps, measles and rubella vaccine. J Epidemiol Community Health 2007:61:797-801.

13 Pearce A, Law C, Elliman D, et al. Factors associated with uptake of measles, mumps, and rubella vaccine (MMR) and use of single antigen vaccines in a contemporary UK cohort: prospective cohort study. BMJ 2008;336:754-7.

14 Pebody RG, Hippisley-Cox J, Harcourt S, et al. Uptake of pneumococcal polysaccharide vaccine in at-risk populations in England and Wales 1999-2005. Epidemiol Infect 2008;136:360-9.

15 Pruitt SL, Schootman M. Geographic disparity, area poverty, and human papillomavirus vaccination. Am J Prev Med 2010;38:525-33.

16 Roberts SA, Brabin L, Stretch R, et al. Human papillomavirus vaccination and social inequality: results from a prospective cohort study. Epidemiol Infect 2011:139:400-5.

17 Spencer AM, Roberts SA, Brabin L, et al. Sociodemographic factors predicting mother's cervical screening and daughter's HPV vaccination uptake. J Epidemiol Community Health 2014;68:571-7.

18 The President's Cancer Panel. Accelerating HPV vaccine uptake: urgency for action to prevent cancer. Bethesda, MD: National Cancer Institute, 2014.

19 National Institue for Health and Care Excellence. Immunisations: reducing differences in uptake in under 19s. London, UK: NICE, 2009.

20 Barbaro B, Brotherton JML. Assessing HPV vaccine coverage in Australia by geography and socioeconomic status: are we protecting those most at risk? Aust $N$ Z J Public Health 2014;38:419-23.

21 Fisher $\mathrm{H}$, Trotter $\mathrm{CL}$, Audrey $\mathrm{S}$, et al. Inequalities in the uptake of human papillomavirus vaccination: a systematic review and meta-analysis. Int J Epidemio/ 2013;42:896-908.

22 McIntyre PB, Menzies RI. Immunisation: reducing health inequality for Indigenous Australians. Med J Aust 2005;182:207-8.

23 Ruijs WLM, Hautvast JLA, van Ansem WJC, et al. Measuring vaccination coverage in a hard to reach minority. Eur J Public Health 2012;22:359-64.

24 Tomkins A, Duff J, Fitzgibbon A, et al. Controversies in faith and health care. Lancet 2015;386:1776-85.

25 The National Collaborating Centre for Women's and Children's Health. Reducing differences in the uptake of immunisations (including targeted vaccines) in children and young people aged under 19 years: systematic review of effectiveness and cost effectiveness evidence. London, UK: NICE, 2009.

26 Moher D, Liberati A, Tetzlaff J, et al. Preferred reporting items for systematic reviews and meta-analyses: the PRISMA statement. BMJ 2009;339:b2535.

27 List of OECD member countries. http://www.oecd.org/about/membersandpartners/ list-oecd-member-countries.htm (accessed 7 Mar 2016).

28 Abdullahi Leila $\mathrm{H}$, Kagina BMN, Wiysonge Charles $\mathrm{S}$, et al. Improving vaccination uptake among adolescents. Cochrane Database Syst Rev 2015;(9):CD011895.

29 Aigbogun NW, Hawker Jl, Stewart A, et al. Interventions to increase influenza vaccination rates in children with high-risk conditions - a systematic review. Vaccine 2015:33:759-70.

30 Bassani DG, Arora P, Wazny K, et al. Financial incentives and coverage of child health interventions: a systematic review and meta-analysis. BMC Public Health 2013;13(Suppl 3):S30.

31 Cawley J, Hull HF, Rousculp MD, et al. Strategies for implementing school-located influenza vaccination of children: a systematic literature review. J Sch Health 2010;80:167-75.

32 Chachou MJ, Mukinda FK, Motaze V, et al. Electronic and postal reminders for improving immunisation coverage in children: protocol for a systematic review and meta-analysis. BMJ Open 2015;5:e008310.

33 Ferrer HB, Trotter C, Hickman M, et al. Barriers and facilitators to HPV vaccination of young women in high-income countries: a qualitative systematic review and evidence synthesis. BMC Public Health 2014;14:700.

34 Community Preventive Services Task Force. Recommendation for use of immunization information systems to increase vaccination rates. J Public Health Manag Pract 2015;21:249-52.

35 Fu LY, Bonhomme LA, Cooper SC, et al. Educational interventions to increase HPV vaccination acceptance: a systematic review. Vaccine 2014;32:1901-20.

36 Groom H, Hopkins DP, Pabst LJ, et al. Immunization information systems to increase vaccination rates: a community guide systematic review. J Public Health Manag Pract 2015;21:227-48

37 Harvey H, Reissland N, Mason J. Parental reminder, recall and educational interventions to improve early childhood immunisation uptake: a systematic review and meta-analysis. Vaccine 2015;33:2862-80.

38 Ames HM, Glenton C, Lewin S. Parents' and informal caregivers' views and experiences of routine early childhood vaccination communication: qualitative evidence synthesis (protocol). Cochrane Database Syst Rev 2015;7:CD011787. 
39 Kaufman J, Synnot A, Ryan R, et al. Face to face interventions for informing or educating parents about early childhood vaccination. Cochrane Satabase Syst Rev 2013;(5):CD010038.

40 Jarrett $C$, Wilson $\mathrm{R}, \mathrm{O}^{\prime}$ Leary $\mathrm{M}$, et al. Strategies for addressing vaccine hesitancy-a systematic review. Vaccine 2015;33:4180-90.

41 Jones Cooper SN, Walton-Moss B. Using reminder/recall systems to improve influenza immunization rates in children with asthma. J Pediatr Health Care 2013;27:327-33

42 Lau AYS, Sintchenko V, Crimmins J, et al. Protocol for a randomised controlled trial examining the impact of a web-based personally controlled health management system on the uptake of influenza vaccination rates. BMC Health Serv Res 2012;12:86

43 Niccolai LM, Hansen CE. Practice- and community-based interventions to increase human papillomavirus vaccine coverage: a systematic review. JAMA Pediatr 2015;169:686-92.

44 Odone A, Ferrari A, Spagnoli $F$, et al. Effectiveness of interventions that apply new media to improve vaccine uptake and vaccine coverage. Hum Vaccin Immunother 2015;11:72-82.

45 Scott A, Sivey P, Ait Ouakrim D, et al. The effect of financial incentives on the quality of health care provided by primary care physicians. Cochrane database Syst Rev 2011;(9):CD008451.

46 Simone B, Carrillo-Santisteve P, Lopalco PL. Healthcare workers role in keeping MMR vaccination uptake high in Europe: a review of evidence. Euro Surveill 2012;17:20206.

47 Wigham S, Ternent L, Bryant A, et al. Parental financial incentives for increasing preschool vaccination uptake: systematic review. Pediatrics 2014;134:e1117-28.

48 Williams N, Woodward H, Majeed A, et al. Primary care strategies to improve childhood immunisation uptake in developed countries: systematic review. JRSM Short Rep 2011;2:81.

49 Willis N, Hill S, Kaufman J, et al. "Communicate to vaccinate": the development of a taxonomy of communication interventions to improve routine childhood vaccination. BMC Int Health Hum Rights 2013;13:23.

50 Craig P, Dieppe P, Macintyre $S$, et al. Developing and evaluating complex interventions: new guidance. London, UK: 2008.

51 Findley SE, Irigoyen $M$, Sanchez $M$, et al. Effectiveness of a community coalition for improving child vaccination rates in New York City. Am J Public Health 2008;98:1959-62.

52 Fu LY, Weissman M, McLaren R, et al. Improving the quality of immunization delivery to an at-risk population: a comprehensive approach. Pediatrics 2012;129: e496-503.

53 Suryadevara M, Bonville CA, Ferraioli $F$, et al. Community-centered education improves vaccination rates in children from low-income households. Pediatrics 2013;132:319-25.

54 Isaac MR, Chartier M, Brownell M, et al. Can opportunities be enhanced for vaccinating children in home visiting programs? A population-based cohort study. BMC Public Health 2015;15:620.

55 Hambidge SJ, Phibbs SL, Chandramouli V, et al. A stepped intervention increases well-child care and immunization rates in a disadvantaged population. Pediatrics 2009;124:455-64.

56 Cockman $P$, Dawson $L$, Mathur $R$, et al. Improving MMR vaccination rates: herd immunity is a realistic goal. BMJ 2011;343:d5703.

57 Thomas P, Joseph TL, Menzies RI, et al. Evaluation of a targeted immunisation program for Aboriginal and Torres Strait Islander infants in an urban setting. N S W Public Health Bull 2008;19:96-9.

58 Potts A, Sinka K, Love J, et al. High uptake of hpv immunisation in scotlandperspectives on maximising uptake. Euro Surveill 2013;18:20593.

59 Sinka K, Kavanagh K, Gordon R, et al. Achieving high and equitable coverage of adolescent HPV vaccine in Scotland. J Epidemiol Community Health 2014:68:57-63.

60 Cates JR, Shafer A, Diehl SJ, et al. Evaluating a county-sponsored social marketing campaign to increase mothers' initiation of HPV vaccine for their pre-teen daughters in a primarily rural area. Soc Mar Q 2011;17:4-26.

61 Cates JR, Diehl SJ, Crandell JL, et al. Intervention effects from a social marketing campaign to promote HPV vaccination in preteen boys. Vaccine 2014;32:4171-8.

62 Moss JL, Reiter PL, Dayton A, et al. Increasing adolescent immunization by webinar: a brief provider intervention at federally qualified health centers. Vaccine 2012;30:4960-3.

63 Chung RJ, Walter EB, Kemper AR, et al. Keen on teen vaccines: improvement of adolescent vaccine coverage in rural North Carolina. J Adolesc Health 2015;56: s14-6.

64 Zimmerman RK, Nowalk MP, Lin CJ, et al. Cluster randomized trial of a toolkit and early vaccine delivery to improve childhood influenza vaccination rates in primary care. Vaccine 2014;32:3656-63.

65 Nowalk MP, Lin CJ, Hannibal K, et al. Increasing childhood influenza vaccination: a cluster randomized trial. Am J Prev Med 2014;47:435-43.
66 Logue E, Dudley P, Imhoff T, et al. An opt-out influenza vaccination policy improves immunization rates in primary care. J Health Care Poor Underserved 2011;22:232-42

67 Vora S, Verber L, Potts S, et al. Effect of a novel birth intervention and reminder-recall on on-time immunization compliance in high-risk children. Hum Vaccin 2009;5:395-402.

68 Meghea $\mathrm{Cl}$, Li B, Zhu Q, et al. Infant health effects of a nurse-community health worker home visitation programme: a randomized controlled trial. Child Care Health Dev 2013;39:27-35.

69 Kattan JA, Kudish KS, Cadwell BL, et al. Effect of vaccination coordinators on socioeconomic disparities in immunization among the 2006 Connecticut birth cohort. Am J Public Health 2014;104:e74-81.

70 Kempe A, Saville A, Dickinson LM, et al. Population-based versus practice-based recall for childhood immunizations: a randomized controlled comparative effectiveness trial. Am J Public Health 2013;103:1116-23.

71 Kempe A, Saville AW, Dickinson LM, et al. Collaborative centralized reminder/recall notification to increase immunization rates among young children: a comparative effectiveness trial. JAMA Pediatr 2015;169:365-73.

72 Atchison C, Zvoc M, Balakrishnan R, et al. The evaluation of a standardized call/ recall system for childhood immunizations in Wandsworth, England. I Community Health 2013:38:581-7.

73 Dombkowski KJ, Costello LE, Harrington LB, et al. Age-specific strategies for immunization reminders and recalls: a registry-based randomized trial. Am J Prev Med 2014:47:1-8.

74 Lemstra M, Rajakumar D, Thompson A, et al. The effectiveness of telephone reminders and home visits to improve measles, mumps and rubella immunization coverage rates in children. Paediatr Child Health 2011;16:e1-5.

75 Cushon JA, Neudorf CO, Kershaw TM, et al. Coverage for the entire population: tackling immunization rates and disparities in Saskatoon Health Region. Can J Public Health 2012;103:eS37-41.

76 Stockwell MS, Kharbanda EO, Martinez RA, et al. Text4Health: impact of text message reminder-recalls for pediatric and adolescent immunizations. Am J Public Health 2012;102:e15-21.

77 Hofstetter AM, DuRivage N, Vargas CY, et al. Text message reminders for timely routine MMR vaccination: a randomized controlled trial. Vaccine 2015;33:5741-6.

78 Abbott P, Menzies R, Davison J, et al. Improving immunisation timeliness in Aboriginal children through personalised calendars. BMC Public Health 2013;13:598.

79 Kharbanda EO, Stockwell MS, Fox HW, et al. Text message reminders to promote human papillomavirus vaccination. Vaccine 2011;29:2537-41.

80 Szilagyi PG, Humiston SG, Gallivan S, et al. Effectiveness of a citywide patient immunization navigator program on improving adolescent immunizations and preventive care visit rates. Arch Pediatr Adolesc Med 2011;165:547-53.

81 Bar-Shain DS, Stager MM, Runkle AP, et al. Direct messaging to parents/guardians to improve adolescent immunizations. J Adolesc Health 2015;56:S21-6.

82 Brigham KS, Woods ER, Steltz SK, et al. Randomized controlled trial of an immunization recall intervention for adolescents. Pediatrics 2012;130:507-14.

83 Morris J, Wang W, Wang L, et al. Comparison of reminder methods in selected adolescents with records in an immunization registry. J Adolesc Health 2015;56: S27-32.

84 Mantzari E, Vogt F, Marteau TM. Financial incentives for increasing uptake of HPV vaccinations: a randomized controlled trial. Health Psychol 2015;34:160-71.

85 Stockwell MS, Kharbanda EO, Martinez RA, et al. Effect of a text messaging intervention on influenza vaccination in an urban, low-income pediatric and adolescent population: a randomized controlled trial. JAMA 2012;307:1702-8.

86 Stockwell MS, Hofstetter AM, DuRivage $N$, et al. Text message reminders for second dose of influenza vaccine: a randomized controlled trial. Pediatrics 2015;135: e83-91.

87 Hofstetter AM, Vargas CY, Camargo S, et al. Impacting delayed pediatric influenza vaccination: a randomized controlled trial of text message reminders. Am J Prev Med 2015:48:392-401.

88 Ruffin MT 4th, Plegue MA, Rockwell PG, et al. Impact of an electronic health record (EHR) reminder on human papillomavirus (HPV) vaccine initiation and timely completion. J Am Board Fam Med 2015;28:324-33.

89 Szilagyi PG, Serwint JR, Humiston SG, et al. Effect of provider prompts on adolescent immunization rates: a randomized trial. Acad Pediatr 2015;15:149-57.

90 DiClemente RJ, Murray CC, Graham T, et al. Overcoming barriers to HPV vaccination: a randomized clinical trial of a culturally-tailored, media intervention among African American girls. Hum Vaccin Immunother 2015;11:2883-94.

91 Rickert VI, Auslander BA, Cox DS, et al. School-based HPV immunization of young adolescents: effects of two brief health interventions. Hum Vaccin Immunother 2015;11:315-21.

92 Marmot M. The health gap: the challenge of an unequal world. Lancet 2015;386:2442-4.

93 Glatman-Freedman A, Nichols K. The effect of social determinants on immunization programs. Hum Vaccin Immunother 2012;8:293-301. 